\title{
KARAKTERISTIK FISIKOKIMIA DAN SENSORI VELVA TOMAT (Lycopersicum esculentum Mill) DENGAN PEMANIS MADU
}

\section{PHYSICOCHEMICAL AND SENSORY CHARACTERISTICS OF VELVA TOMATOES (Lycopersicum esculentum Mill) WITH HONEY SWEETENER}

\author{
Raisa Sapriyanti ${ }^{1)}$, Edhi Nurhartadi ${ }^{2)}$, Dwi Ishartani ${ }^{2)}$ \\ ${ }^{l}$ Alumni Program Studi Ilmu dan Teknologi Pangan \\ ${ }^{2}$ Staff Pengajar Program Studi Ilmu dan Teknologi Pangan
}

Email: raisa.sapriyanti90@yahoo.co.id

\begin{abstract}
The purpose of this study was to know the effect of variations in the concentration of honey to the physical characteristics (overrun, melting rate, and total soluble solids), chemical characteristics (moisture content, dietary fiber, vitamin $C$, lycopene, and antioxidant activity), and sensory characteristics (preference test and the intensity of sweetness) velva tomatoes produced. This study used a Completely Randomized Design (CRD) with one factor, the variation of the concentration of the use of honey (15\%, 25\%, and 35\%). The data were statistically analyzed by One Way ANOVA, the results obtained if there is a significance difference, then followed by DMRT at $\alpha=0.05$ level. Intensity of sweetness data were analyzed using one-way ANOVA at $\alpha=$ 0.05 level. If there is a significance difference, then later followed by Tukey test. The use of honey to give effect to the physicochemical characteristics of velva tomato is a decrease overrun and moisture content, there is also an increased melting rate, dietary fiber, vitamin $C$, total dissolved solids, lycopene, and antioxidant activity. The utilization of honey gives a decrease of score from panelist on parameter color and flavor, but gives a increase of score on parameter taste, texture, and overall. In the sweetness intensity test it is known that velva tomato with concentration of honey 15\% has sweetnees intensity is higher better than sucrose 25\%, and velva tomato with concentration of honey $25 \%$ and $35 \%$ has sweetnees intensity is lower better than sucrose $25 \%$.
\end{abstract}

Keywords: honey, tomato, velva

\section{ABSTRAK}

Penelitian ini bertujuan untuk mengetahui pengaruh variasi konsentrasi penggunaan madu terhadap karakteristik fisik (overrun, daya leleh, dan total padatan terlarut), karakteristik kimia (kadar air, serat pangan, vitamin $\mathrm{C}$, likopen, dan aktivitas antioksidan), dan karakteristik sensori (uji kesukaan dan intensitas kemanisan) velva tomat yang dihasilkan. Penelitian ini menggunakan Rancangan Acak Lengkap (RAL) dengan satu faktor, yaitu variasi konsentrasi penggunaan madu $(15 \%, 25 \%$, dan 35\%). Data dianalisis secara statistik dengan One Way ANOVA, apabila hasil yang diperoleh ada beda nyata, maka dilanjutkan dengan uji DMRT dengan $\alpha=0,05$. Untuk data yang diperoleh dari uji intensitas kemanisan, dianalisis menggunakan one way ANOVA pada tingkat $\alpha=0,05$. Jika terdapat perbedaan nyata, maka kemudian dilanjutkan dengan uji Tukey. Hasil penelitian menunjukkan bahwa penggunaan madu berpengaruh nyata terhadap karakteristik fisikokimia velva tomat berupa penurunan overrun dan kadar air, terjadi pula peningkatan daya leleh, padatan terlarut, serat pangan, vitamin $\mathrm{C}$, likopen, dan aktivitas antioksidan). Penggunaan madu memberikan penurunan skor penilaian panelis terhadap parameter warna dan aroma, namun memberikan peningkatan skor penilaian terhadap parameter rasa, tekstur, dan overall. Pada uji intensitas kemanisan diketahui bahwa velva tomat dengan konsentrasi penggunaan madu $15 \%$ memiliki tingkat kemanisan lebih rendah daripada sukrosa $25 \%$, sedangkan velva tomat dengan konsentrasi madu 25\% dan 35\% memiliki tingkat kemanisan yang lebih tinggi dibandingkan sukrosa $25 \%$.

Kata kunci: madu, tomat, velva

\section{PENDAHULUAN}

Setiap tahun sektor pertanian Indonesia memproduksi ribuan ton sayursayuran dan buah-buahan yang beranekaragam. Sayur-sayuran dan buahbuahan mempunyai sifat yang mudah rusak, maka dari itu diperlukan kegiatan penanganan pasca panen untuk mengurangi kerusakan tersebut. Proses pengawetan dan pengolahan menjadi bentuk pangan lain yang lebih stabil baik secara biologis, fisik, dan kimia menjadi pilihan yang tepat dalam kegiatan pasca panen. Salah satu hasil pertanian yang dapat dijadikan produk pangan adalah tomat. Masyarakat Indonesia memanfaatkan tomat untuk menunjang pemenuhan kebutuhan gizi secara bertahap. Tomat umumnya dijadikan sebagai pelengkap bumbu dapur. Selain itu, tomat juga dapat dikonsumsi dalam bentuk buah segar ataupun diolah menjadi sari buah, saos, manisan 
kering, pasta dan dapat digunakan pada industri kecantikan.

Tomat memiliki berbagai vitamin dan senyawa fungsional yang baik bagi kesehatan, salah satunya adalah likopen. Tomat mengandung lemak dan kalori dalam jumlah rendah, bebas kolesterol, dan merupakan sumber serat dan protein yang baik. Selain itu, tomat kaya akan vitamin A dan C, beta-karoten, kalium, dan likopen (Kailaku dkk, 2007). Produksi tomat di Indonesia mulai dari tahun 2006 hingga 2011 terus menunjukkan peningkatan. Pada tahun 2011, produksi tomat di Indonesia mencapai 954,046 ton (Badan Pusat Statistik Indonesia, 2013). Ketersediaan tomat yang melimpah dan kandungan gizi yang sangat bermanfaat untuk kesehatan, maka perlu dilakukan diversifikasi olahan agar dapat meningkatkan potensi pemasaran tomat sebagai produk olahan yang memiliki nilai tambah.

Salah satu produk diversifikasi yang dapat meningkatkan nilai ekonomis dari buah tomat adalah velva. Velva merupakan salah satu jenis makanan beku serupa dengan es krim tetapi mempunyai kadar lemak rendah karena tidak menggunakan lemak susu dan mempunyai kandungan vitamin $\mathrm{C}$ dan serat yang tinggi (Dewi, 2010). Produk ini sangat sesuai bila dikonsumsi oleh kelompok vegetarian maupun orang-orang yang sedang diet rendah lemak (Rizqa, 2013).

Velva terbuat dari campuran puree buah, gula, bahan penstabil, dan air. Salah satu komponen penyusunnya adalah gula. Gula dalam pembuatan produk makanan beku dapat digunakan sebagai pemanis serta dapat memperbaiki body dan tekstur. Gula dapat membantu mencegah pembentukan kristal es yang besar selama pembekuan. Peningkatan kadar gula akan mengakibatkan kekentalan dan tekstur produk makanan beku (Dewi, 2010). Namun penggunaan gula yang berlebih dapat mengakibatkan obesitas karena tubuh tidak mengubahnya menjadi energi tetapi disimpan di dalam sel sebagai timbunan lemak. Maka penggunaan gula dalam produk pangan harus dibatasi atau diganti dengan bahan pemanis lain yang aman bila dikonsumsi oleh tubuh. Selain itu, gula hanya menyumbang energi tetapi tidak mempunyai komponen fungsional yang dapat meningkatkan nilai fungsional produk. Alternatif pemanis lain yang mempunyai komponen fungsional adalah madu.

Madu adalah cairan manis yang dihasilkan oleh lebah madu berasal dari sumber nektar (SNI 01-3504-2004). Madu dapat digunakan sebagai pemanis alami pada produk pangan. Keuntungan menggunakan madu sebagai pemanis bila dibandingkan dengan gula (sukrosa), yaitu madu memiliki nilai kalori yang lebih tinggi daripada gula dan rasanya lebih manis daripada gula sehingga penggunaan madu dapat dikurangi bila dibandingkan apabila menggunakan gula. Kedua, gula merupakan sukrosa yang terdiri dari dua molekul yang terikat bersama. Ketika mengkonsumsi gula, tubuh harus menggunakan enzim yang dihasilkan sendiri untuk memisahkan molekul-molekul tersebut sebelum dapat digunakan energinya, sedangkan pada madu sudah terdapat enzim khusus untuk memecah sukrosa menjadi glukosa dan fruktosa sehingga dapat langsung diserap tubuh. Selain itu, gula tidak mengandung vitamin dan sedikit mineral, sedangkan madu mengandung vitamin dan mineral yang cukup banyak. Gula memanfaatkan nutrisi tubuh untuk dimetabolisme ke dalam sistem. Ketika nutrisi ini semua sudah digunakan, metabolisme kolesterol dan asam lemak yang tidak diinginkan terhambat, berkontribusi terhadap naiknya kadar kolesterol dan obesitas akibat asam lemak yang lebih tinggi pada organ dan jaringan (Gosyenland, 2010). Penggunaan madu pada produk pangan lebih unggul daripada menggunakan gula (sukrosa).

Madu mengandung vitamin A, B1, B2, B3, B5, B6, C, D, E, K, beta karoten, flavonoid, asam fenolik, asam urat dan asam nikotinat. Di dalam madu juga terdapat kandungan mineral dan garam atau zat lain seperti zat besi, sulfur, magnesium, kalsium, kalium, khlor, natrium, fosfor dan sodium serta antibiotik dan enzim pencernaan. Kandungan nutrisi dalam madu yang berfungsi sebagai antioksidan adalah vitamin C, asam organik, enzim, asam fenolik, flavonoid dan beta karoten yang bermanfaat sebagai antioksidan tinggi serta vitamin A, vitamin E yang juga merupakan salah satu 
vitamin antioksidan esensial yang utama. Dengan demikian pada madu terdapat banyak nutrisi yang berfungsi sebagai antioksidan dan semua senyawa tersebut bekerjasama dalam melindungi sel normal dan menetralisir radikal bebas (Parwata dkk, 2010).

Berdasarkan uraian di atas dapat diketahui bahwa madu memiliki tingkat kemanisan, kandungan gizi, dan komponen fungsional yang lebih tinggi daripada sukrosa sehingga dapat dijadikan alternatif pemanis pengganti gula dalam pembuatan velva. Sukrosa mempunyai peran penting dalam pembuatan velva sebagai pembentuk tekstur dan memberikan rasa manis pada velva. Penggantian sukrosa dengan madu diduga akan mempengaruhi karakteristik fisikomia dan sensori dari velva sehingga perlu dilakukan penelitian mengenai velva yang menggunakan pemanis berupa madu.

\section{METODE PENELITIAN}

\section{Bahan dan Alat}

Bahan utama yang digunakan dalam pembuatan velva tomat, yaitu tomat buah segar yang diperoleh dari Pasar Legi Surakarta, madu, asam sitrat, gula pasir, gum arab dan CMC. Tomat yang digunakan adalah tomat dengan varietas lokal Tawangmangu dengan tingkat kematangan merah masak ditandai dengan daging buah tebal dan tekstur buah lunak. CMC dan asam sitrat diperoleh dari toko bahan kimia "Saba" Surakarta, gum arab teknis diperoleh dari Toko Multi Kimia Raya Semarang produksi PT. Indesso Niagatama, Purwokerto, Jawa tengah, gula pasir yang digunakan (Gulaku) diperoleh dari supermarket Luwes Surakarta dan madu yang digunakan adalah jenis madu kelengkeng yang diperoleh dari Perhutani Surakarta. Untuk bahan-bahan kimia yang digunakan untuk analisis sifat kimia, yaitu buffer Na-phosphat $0,1 \mathrm{M}, \mathrm{HCl} 4 \mathrm{~N}, \mathrm{NaOH}$, enzim termamyl, enzim pepsin, enzim pankreatin, etanol $95 \%$ dan $78 \%$, aseton, indikator pati, larutan iod 0,01 N, BHT (Butil Hidroksi Toluen) 0,01\%, heksan, larutan DPPH (1,1-Diphenyl-2-picrylhydrazyl), methanol, dan aquades.
Alat yang digunakan dalam pembuatan velva tomat, yaitu pisau, baskom, panci, blender (GMC BL-001), mixer (Miyako Hand Mixer HM-620), dan freezer (Modena Dual Function). Alat untuk analisis, yaitu spektrofotometer UV-Vis (Shimadzu), oven (Memmert), waterbath (Memmert), crucible dan celite, refraktometer (Atago), tanur (Barnstead Thermolyne), shaker waterbath (IKA KS 130 Basic), timbangan analitik (Ohaus Adventurer), botol timbang, desikator (IWAKI), vortex (Heidolph Reax Control), labu takar $100 \mathrm{ml}$, erlenmeyer 250 $\mathrm{ml}$, buret, tabung reaksi $10 \mathrm{ml}$, gelas ukur, pipet volume $1 \mathrm{ml}, 10 \mathrm{ml}$, dan $5 \mathrm{ml}$ (Pyrex).

\section{Tahapan Penelitian}

Tahapan penelitian dibagi menjadi dua tahap, yaitu penelitian pendahuluan dan penelitian utama.

\section{Penelitian Pendahuluan}

Penelitian pendahuluan dilakukan untuk menentukan konsentrasi penambahan madu pada velva tomat. Perbandingan konsentrasi buah dan air yang digunakan dalam pembuatan velva tomat mengacu pada penelitian sebelumnya, yaitu penelitian Suraningsih (2000). Jumlah perbandingan buah dan air pada velva sirsak yang digunakan 1: 2 dengan konsentrasi gula $25 \%$ untuk menghasilkan tekstur, warna, dan aroma velva yang terbaik. Sedangkan penentuan konsentrasi penambahan madu mengacu pada penelitian Aji (2011) pada minuman sari buah naga.

\section{Penelitian Utama}

Proses pembuatan velva tomat dimulai dengan persiapan bahan baku. Buah tomat dikupas, diambil daging buahnya, dibuang biji dan bagian lain yang tidak dapat dimakan, kemudian dipotongpotong. Potongan daging buah tersebut selanjutnya dihancurkan dengan blender sampai menjadi bubur buah (puree) selama kurang lebih 5 menit. Gula pasir ditambahkan ke dalam puree sebanyak $25 \%$. Untuk pembuatan velva dengan menggunakan madu, gula pasir diganti dengan konsentrasi madu. Setelah itu ditambah air matang ke dalam puree dengan perbandingan puree dan air (1:2) 
kemudian dihaluskan kembali selama kurang lebih 5 menit sehingga gula menjadi larut. Setelah dihancurkan dalam blender, adonan kemudian disaring untuk menyaring biji dan eksokarp yang masih tertinggal dari buah tomat.

Adonan yang sudah tercampur kemudian diaduk dengan mixer. Pengadukan tahapan ini bertujuan untuk mendapatkan tekstur campuran yang lembut, kental dan merata. Pengadukan pertama dilakukan dengan blender selama kurang lebih 5 menit kemudian tambahkan asam sitrat. Bahan penstabil yang digunakan yaitu kombinasi antara $\mathrm{CMC} 0,5 \%$ dan gum arab 0,25\%, kemudian CMC dilarutkan dengan air panas dan diaduk hingga CMC tercampur rata dengan air, sedangkan gum arab dilarutkan dengan air dingin hingga larut. Adonan setelah ditambahkan bahan penstabil kemudian didinginkan pada suhu $5-6^{\circ} \mathrm{C}$ selama 8-12 jam. Setelah didinginkan, velva kembali diaduk dengan mixer. Pengadukan kedua dilakukan dengan mixer selama 15 menit. Tahap terakhir yaitu pembekuan velva tomat ke dalam freezer pada suhu $-20^{\circ} \mathrm{C}$ selama 3-4 jam. Velva tomat disimpan dalam freezer untuk membentuk tekstur yang lebih baik.

\section{HASIL DAN PEMBAHASAN}

Pembuatan velva tomat diawali dengan pembuatan puree tomat dengan cara blanching dan penghancuran. Adonan puree tomat ditambahkan bahan penstabil, asam sitrat, dan madu sebagai pemanis pengganti sukrosa kemudian diaduk. Pada tahap pengadukan, adonan yang ditambahkan madu menghasilkan busa yang dapat merusak tekstur velva pada saat dibekukan. Busa yang dihasilkan kemudian dipisahkan secara manual dan adonan velva didinginkan. Setelah didinginkan, velva diaduk dan dibekukan. Penghilangan busa secara manual membuat proses pembuatan velva menjadi kurang efisien sehingga perlu diperbaiki teknik penghilangan busa supaya pembuatan velva menjadi lebih efisien.

\section{Karakteristik Fisik}

\section{Overrun}

Overrun merupakan persentase rasio pengembangan produk. Hasil analisis menunjukkan bahwa konsentrasi penggunaan madu memberikan pengaruh yang berbeda terhadap nilai overrun sampel velva tomat. Hasil analisis sidik ragam menunjukkan bahwa penggunaan madu pada konsentrasi $15-35 \%$ memberikan pengaruh yang nyata terhadap daya pengembangan (overrun) velva tomat. Pada Tabel 1 terlihat adanya kecenderungan penurunan overrun mulai dari konsentrasi penggunaan madu $15 \%$ hingga konsentrasi penggunaan madu 35\%. Semakin tinggi konsentrasi penggunaan madu yang digunakan, adonan semakin kental sehingga tegangan permukaan adonan menjadi lebih tinggi. Hal ini berakibat udara sukar menembus permukaan adonan sehingga produk lebih sukar mengembang. Hal ini sesuai dengan pernyataan Arbuckle dan Marshall (1996) bahwa jika kekentalan adonan meningkat maka daya pengembangan (overrun) akan menurun. Berdasarkan uraian di atas dapat diduga bahwa semakin tinggi konsentrasi penggunaan madu maka nilai overrun semakin turun.

\section{Daya Leleh}

Daya leleh didefinisikan sebagai waktu yang dibutuhkan oleh es krim untuk meleleh sempurna pada suhu ruang. Kecepatan pelelehan adalah waktu yang dibutuhkan oleh velva untuk meleleh sempurna. Penggunaan madu pada konsentrasi 15-35\% memberikan pengaruh yang nyata terhadap daya leleh velva tomat. Pada Tabel 1 terlihat adanya kecenderungan peningkatan daya leleh mulai dari konsentrasi penggunaan madu $15 \%$ hingga konsentrasi penggunaan madu $35 \%$. Velva tomat yang menggunakan pemanis madu $15 \%$ dan $25 \%$ mempunyai daya leleh yang lebih rendah dibandingkan dengan velva tomat kontrol yang menggunakan pemanis sukrosa $25 \%$. Namun velva tomat yang menggunakan pemanis madu $35 \%$ mempunyai daya leleh yang lebih tinggi dibandingkan dengan velva tomat kontrol. Kemampuan fruktosa pada madu untuk mengikat air menyebabkan molekul-molekul air terperangkap sehingga 
Tabel 1. Pengaruh Variasi Konsentrasi Penggunaan Madu terhadap Sifat Fisik Velva Tomat.

\begin{tabular}{cccc}
\hline Formula* $^{*}$ & $\begin{array}{c}\text { Overrun } \\
(\%)^{* *}\end{array}$ & Daya leleh** & $\begin{array}{c}\text { Total padatan terlarut } \\
\left({ }^{\circ} \text { Brix }\right)^{* *}\end{array}$ \\
\hline Kontrol & $16,96^{\mathrm{b}}$ & 15 menit 10 detik $^{\mathrm{c}}$ & $19,67^{\mathrm{d}}$ \\
F1 & $22,12^{\mathrm{d}}$ & 12 menit $47 \operatorname{detik}^{\mathrm{a}}$ & $10,17^{\mathrm{a}}$ \\
F2 & $18,27^{\mathrm{c}}$ & 13 menit $54 \operatorname{detik}^{\mathrm{b}}$ & $14,33^{\mathrm{b}}$ \\
F3 & $15,76^{\mathrm{a}}$ & 15 menit $26 \operatorname{detik}^{\mathrm{d}}$ & $17,67^{\mathrm{c}}$ \\
\hline
\end{tabular}

Keterangan : *) Kontrol = velva tomat dengan pemanis gula $25 \%$, F1 = velva tomat dengan pemanis madu $15 \%$, $\mathrm{F} 2=$ velva tomat dengan pemanis madu $25 \%, \mathrm{~F} 3$ = velva tomat dengan pemanis madu $35 \%$.

**) Angka yang diikuti huruf yang berbeda pada kolom yang sama menunjukan adanya beda nyata pada taraf sig $\alpha=0,05$.

kekentalan adonan dan daya leleh meningkat. Hal ini sesuai dengan pernyataan Arbuckle and Marshall (1996) bahwa total padatan yang rendah memiliki resistensi terhadap pelelehan yang rendah sehingga akan mudah meleleh.

\section{Total Padatan Terlarut}

Total padatan terlarut (total soluble solid) umumnya dinyatakan dalam satuan persen gula sukrosa. Padatan terlarut yang terkandung dalam suatu produk pangan terdiri atas komponen-komponen yang larut dalam air seperti glukosa, fruktosa, sukrosa, dan protein yang larut dalam air. Peningkatan nilai padatan terlarut juga dihubungkan dengan penurunan kadar air (Vail et al., 1978 cit Setianawati, 2002). Padatan dalam velva tomat berasal dari puree buah, gula, madu, asam sitrat, dan bahan penstabil. Berdasarkan Tabel 1 dapat dilihat bahwa penggunaan madu berpengaruh nyata terhadap peningkatan nilai total padatan terlarut pada velva tomat. Perlakuan velva tomat kontrol yang menggunakan pemanis sukrosa memiliki nilai total padatan terlarut yang lebih tinggi dibandingkan dengan velva tomat dengan perlakuan penggunaan madu. Hal ini dikarenakan pada metode refraktometri, total padatan terlarut diukur dari persen massa sukrosa yang larut dalam adonan. Menurut Hammad (2009), kandungan sukrosa pada madu hanya $1,5 \%$ dalam 100 gram madu. Sedangkan pada velva tomat kontrol terkandung 25\% sukrosa sehingga kandungan sukrosa pada velva tomat kontrol lebih tinggi daripada velva tomat dengan perlakuan penggunaan madu. Semakin tinggi konsentrasi madu yang ditambahkan, nilai total padatan terlarut velva tomat semakin meningkat.

\section{Karakteristik Kimia}

\section{Kadar Air}

Air merupakan salah satu karakteristik yang sangat penting pada bahan makanan karena air dapat mempengaruhi penampakan, tekstur, serta cita rasa makanan. Kandungan air dalam bahan makanan berperan menentukan daya terima, kesegaran, dan umur simpan bahan pangan. Kandungan air juga sangat mempengaruhi sifat fisik, kimia, mikrobiologi, dan enzimatis pada bahan makanan (Winarno, 2004). Perhitungan kadar air pada penelitian ini berdasarkan persen basis basah (wet basis). Berdasarkan Tabel 2 dapat dilihat bahwa kadar air tertinggi pada velva tomat yang menggunakan pemanis madu ditunjukkan pada velva konsentrasi pemanis madu 15\% (F1), yaitu sebesar $87,70 \%$ (wb) dan kadar air terendah ditunjukkan pada velva tomat dengan konsentrasi pemanis madu 35\% (F3), yaitu sebesar 71,98\% (wb). Jika dibandingkan dengan velva tomat kontrol yang menggunakan pemanis sukrosa dengan kadar air sebesar 80,97\% (wb), velva tomat yang menggunakan pemanis madu $15 \%$ memiliki kadar air yang lebih tinggi. Sedangkan velva tomat yang menggunakan pemanis madu $25 \%$ dan $35 \%$ memiliki kadar air yang lebih rendah dibandingkan dengan velva tomat kontrol yang menggunakan pemanis sukrosa $25 \%$. Penggunaan madu memberikan pengaruh yang nyata terhadap kadar air velva tomat. Semakin tinggi konsentrasi madu yang ditambahkan, kadar air velva tomat semakin turun. Pengaruh nyata pada kadar air velva tomat diduga dipengaruhi oleh komposisi serat dan mineral yang terdapat pada madu sehingga menambah total padatan dalam adonan. Meningkatnya total padatan dalam 
Tabel 2. Pengaruh Variasi Konsentrasi Penggunaan Madu terhadap Sifat Kimia Velva Tomat.

\begin{tabular}{cccccc}
\hline Formula* & $\begin{array}{c}\text { Kadar air** } \\
(\% \mathrm{wb})\end{array}$ & $\begin{array}{c}\text { Serat } \\
\text { pangan** } \\
(\%)\end{array}$ & $\begin{array}{c}\text { Vitamin } \\
\mathrm{C}^{* *} \\
(\mathrm{mg} / 100 \\
\mathrm{g})\end{array}$ & $\begin{array}{c}\text { Kadar } \\
\text { likopen** } \\
(\mathrm{mg} / \mathrm{kg} \mathrm{bb})\end{array}$ & $\begin{array}{c}\text { Aktivitas } \\
\text { antioksidan* } \\
*(\%)\end{array}$ \\
\hline Kontrol & $80,97^{\mathrm{c}}$ & $2,28^{\mathrm{a}}$ & $13,20^{\mathrm{a}}$ & $10,92^{\mathrm{a}}$ & $61,14^{\mathrm{a}}$ \\
F1 & $87,70^{\mathrm{d}}$ & $2,31^{\mathrm{a}}$ & $17,60^{\mathrm{b}}$ & $10,96^{\mathrm{a}}$ & $62,90^{\mathrm{b}}$ \\
F2 & $77,39^{\mathrm{b}}$ & $2,35^{\mathrm{ab}}$ & $22,00^{\mathrm{c}}$ & $11,00^{\mathrm{a}}$ & $64,81^{\mathrm{c}}$ \\
F3 & $71,98^{\mathrm{a}}$ & $2,42^{\mathrm{b}}$ & $27,13^{\mathrm{d}}$ & $11,05^{\mathrm{a}}$ & $67,60^{\mathrm{d}}$ \\
\hline
\end{tabular}

Keterangan : $\left.{ }^{*}\right)$ Kontrol = velva tomat dengan pemanis gula $25 \%, \mathrm{~F} 1=$ velva tomat dengan pemanis madu $15 \%$, F2 = velva tomat dengan pemanis madu $25 \%$, F3 = velva tomat dengan pemanis madu $35 \%$.

**) Angka yang diikuti huruf yang berbeda pada kolom yang sama menunjukan adanya beda nyata pada taraf sig $\alpha$ $=0,05$.

produk, akan menurunkan presentase air yang terkandung di dalam produk sehingga kadar air velva tomat semakin turun.

\section{Serat Pangan}

Serat pangan adalah kelompok polisakarida dan polimer-polimer lain yang tidak dapat dicerna oleh sistem gastrointestinal bagian atas tubuh manusia (Muchtadi, 2000). Serat pangan atau dietary fiber adalah karbohidrat (polisakarida) dan lignin yang tidak dapat dihidrolisis (dicerna) oleh enzim percernaan manusia, dan akan sampai di usus besar (kolon) dalam keadaan utuh sehingga kebanyakan akan menjadi substrat untuk fermentasi bagi bakteri yang hidup di kolon (Silalahi dan Hutagalung, 1994). Berdasarkan Tabel 2 dapat dilihat bahwa penggunaan madu tidak memberikan pengaruh yang nyata terhadap kadar serat pangan velva tomat, kecuali velva tomat dengan penggunaan madu 35\%. Perlakuan velva tomat kontrol yang menggunakan pemanis sukrosa $25 \%$ memiliki kadar serat pangan $2,28 \%$, perlakuan velva tomat yang menggunakan pemanis madu $15 \%$ (F1) sebesar 2,31\%, perlakuan velva tomat yang menggunakan pemanis madu $25 \%$ (F2) sebesar $2,35 \%$, dan perlakuan velva tomat yang menggunakan pemanis madu 35\% (F3) sebesar 2,45\%. Peningkatan kadar serat pangan pada velva tomat, disamping karena bahan baku tomat memiliki serat, juga dipengaruhi oleh penggunaan madu. Sakri (2012) menyatakan bahwa kandungan serat pangan pada madu dalam 100 gram madu sebesar 0,2 gram. Meskipun pengaruh penggunaan madu tidak berbeda nyata terhadap kadar serat pangan velva, namun pola umum kadar serat pangan semakin meningkat. Semakin besar konsentrasi madu yang ditambahkan, semakin meningkat kadar serat pangan velva tomat.

\section{Vitamin C}

Vitamin $\mathrm{C}$ adalah vitamin yang paling tidak stabil di antara semua vitamin yang mudah mengalami kerusakan selama proses pengolahan dan penyimpanan. Vitamin ini memiliki sifat sangat mudah larut dalam air, mudah teroksidasi dalam proses ini dipercepat oleh panas, sinar, alkali, serta oleh katalis tembaga dan besi. (Winarno dan Rahayu, 1994). Berdasarkan Tabel 2 dapat dilihat bahwa penggunaan madu berpengaruh nyata terhadap peningkatan kadar vitamin $\mathrm{C}$ pada velva tomat. Semakin tinggi konsentrasi madu yang ditambahkan, kadar vitamin $\mathrm{C}$ velva tomat semakin meningkat. Perlakuan velva tomat kontrol yang menggunakan pemanis sukrosa memiliki kadar vitamin $\mathrm{C}$ $13,20 \mathrm{mg} / 100 \mathrm{~g}$, perlakuan penggunaan madu $15 \%$ (F1) sebesar 17,60 mg/100g, perlakuan penggunaan madu 25\% (F2) sebesar 22,00 $\mathrm{mg} / 100 \mathrm{~g}$, dan perlakuan penggunaan madu $35 \% \quad$ (F3) sebesar 27,13 $\mathrm{mg} / 100 \mathrm{~g}$. Peningkatan kadar vitamin $\mathrm{C}$ pada velva tomat, di samping karena bahan baku tomat mengandung vitamin $\mathrm{C}$ juga dipengaruhi oleh penggunaan madu. Menurut Food and Nutrition Encyclopedia (1994) cit. Muhsin (2008), madu mengandung vitamin $\mathrm{C}$ sebesar $1 \mathrm{mg}$ dalam 100 gram madu. Semakin besar konsentrasi madu yang ditambahkan maka semakin tinggi kadar vitamin $\mathrm{C}$ pada velva tomat. 


\section{Likopen}

Likopen adalah hidrokarbon alifatik yang mengandung tiga belas ikatan rangkap dengan formula $\mathrm{C}_{40} \mathrm{H}_{56}$ (Thompson et al., 2000). Likopen dapat berfungsi sebagai antioksidan karena memiliki sebelas ikatan rangkap terkonjugasi yang dapat menahan serangan radikal bebas membentuk produk inaktif, sehingga radikal bebas menjadi stabil (Chew, 1995). Berdasarkan Tabel 2 dapat dilihat bahwa perlakuan velva tomat kontrol yang menggunakan pemanis sukrosa memiliki kadar likopen 10,92 $\mathrm{mg} / \mathrm{kg}$ b.b, perlakuan penggunaan madu $15 \%$ (F1) sebesar 10,96 $\mathrm{mg} / \mathrm{kg} \quad$ b.b, perlakuan penggunaan madu 25\% (F2) sebesar 11,00 $\mathrm{mg} / \mathrm{kg}$ b.b, dan perlakuan penggunaan madu $35 \% \quad$ (F3) sebesar $11,05 \quad \mathrm{mg} / \mathrm{kg} \quad$ b.b. Penggunaan madu dengan konsentrasi $15 \%$ $35 \%$ ternyata tidak memberikan pengaruh nyata terhadap peningkatan kadar likopen pada velva tomat. Namun pola umum kadar likopen tomat menunjukkan peningkatan. Kadar likopen pada velva tomat selain berasal dari buah tomat, juga berasal dari penggunaan madu. Menurut Kailaku dkk (2007), kandungan likopen pada buah tomat dengan tingkat kematangan merah sempurna sebesar $46 \mathrm{mg} / \mathrm{kg}$. Madu yang digunakan dalam pembuatan velva adalah madu kelengkeng (monoflora) dan berdasarkan warna madu termasuk ke dalam amber honey (kuning kecoklatan). Menurut Ferreira et al. (2009), kandungan likopen pada amber honey sebesar $6,19 \mathrm{mg} / \mathrm{kg}$. semakin tinggi jumlah penggunaan madu maka semakin tinggi kadar likopen pada velva yang dihasilkan.

\section{Aktivitas Antioksidan}

Aktivitas antioksidan adalah kemampuan suatau bahan dalam meredam efek radikal bebas. Berdasarkan Tabel 2 dapat dilihat bahwa penggunaan madu berpengaruh nyata terhadap peningkatan aktivitas antioksidan pada velva tomat. Velva tomat kontrol yang menggunakan pemanis sukrosa memiliki aktivitas antioksidan yang lebih rendah dibandingkan dengan velva tomat yang menggunakan pemanis madu. Velva tomat yang menggunakan pemanis madu 15\%-35\% menunjukkan peningkatan aktivitas antioksidan. Perlakuan velva tomat kontrol yang menggunakan pemanis sukrosa memiliki aktivitas antioksidan $61,14 \%$, perlakuan penggunaan madu $15 \%$ (F1) sebesar $62,90 \%$, perlakuan penggunaan madu $25 \%$ (F2) sebesar $64,81 \%$, dan perlakuan penggunaan madu 35\% (F3) sebesar $67,60 \%$. Peningkatan aktivitas antioksidan pada velva tomat, di samping karena bahan baku tomat mengandung aktivitas antioksidan juga dipengaruhi oleh penambahan madu. Menurut Ardiansyah (2007), madu merupakan salah satu aplikasi sumber alami yang dapat dimanfaatkan sebagai sumber antioksidan. Kandungan nutrisi dalam madu yang berfungsi sebagai antioksidan adalah vitamin C, asam organik, enzim, asam fenolat, flavonoid dan beta karoten yang bermanfaat sebagai antioksidan tinggi (Gheldof, 2002), serta vitamin A dan vitamin E yang juga merupakan salah satu vitamin antioksidan esensial yang utama (Siregar, 2012).

\section{Karakteristik Sensori}

\section{Uji Kesukaan (Hedonik)}

\section{a) Warna}

Hasil analisis sidik ragam pada Tabel 3 menunjukkan bahwa velva tomat dengan pemanis madu $25 \%$ berbeda nyata terhadap warna velva kontrol. Sedangkan velva tomat dengan pemanis madu $15 \%$ dan $35 \%$ tidak berbeda nyata terhadap warna velva tomat kontrol. Untuk tiga perlakuan, penggunaan pemanis madu $15 \%$ berbeda nyata dengan warna velva tomat yang menggunakan pemanis madu $25 \%$ dan 35\%. Sedangkan penggunaan pemanis madu $25 \%$ tidak berbeda nyata dengan warna velva tomat yang menggunakan pemanis madu $35 \%$. Penggunaan madu menurunkan tingkat kesukaan panelis terhadap parameter mutu warna velva yang dihasilkan. Sihombing (1997) menyatakan bahwa zat pewarna madu sebagian besar belum diketahui, namun ada yang menduga terdiri dari fraksi yang larut air dan larut lemak. Madu yang berwarna cerah, warna zat larut air lebih sedikit dari pada yang larut lemak. Ada juga yang menduga oleh senyawa polifenol, terutama pada madu berwarna pekat. Oksidasi yang 
Tabel 3. Pengaruh Variasi Konsentrasi Penggunaan Madu terhadap Sifat Sensori Velva Tomat.

\begin{tabular}{cccccc}
\hline \multirow{2}{*}{ Formula $^{*}$} & \multicolumn{5}{c}{ Parameter***** $^{* *}$} \\
\cline { 2 - 6 } & Warna & Rasa & Aroma & Tekstur & Overall \\
\hline Kontrol & $2,63^{\mathrm{bc}}$ & $3,03^{\mathrm{c}}$ & $2,57^{\mathrm{b}}$ & $2,53^{\mathrm{ab}}$ & $2,93^{\mathrm{b}}$ \\
F1 & $2,90^{\mathrm{c}}$ & $1,70^{\mathrm{a}}$ & $2,13^{\mathrm{ab}}$ & $2,20^{\mathrm{a}}$ & $2,00^{\mathrm{a}}$ \\
F2 & $2,17^{\mathrm{a}}$ & $1,83^{\mathrm{a}}$ & $2,27^{\mathrm{ab}}$ & $2,33^{\mathrm{a}}$ & $1,97^{\mathrm{a}}$ \\
F3 & $2,27^{\mathrm{ab}}$ & $2,33^{\mathrm{b}}$ & $2,03^{\mathrm{a}}$ & $2,83^{\mathrm{b}}$ & $2,30^{\mathrm{a}}$ \\
\hline
\end{tabular}

Keterangan : *) Kontrol = velva tomat pemanis gula $25 \%, \mathrm{~F} 1=$ velva tomat dengan pemanis madu $15 \%, \mathrm{~F} 2=$ velva tomat dengan pemanis madu $25 \%, \mathrm{~F} 2$ = velva tomat dengan pemanis madu $35 \%$.

**) Angka yang diikuti huruf yang berbeda pada kolom yang sama menunjukan adanya beda nyata pada taraf $\operatorname{sig} \alpha=0,05$.

***) Skor : $1=$ tidak suka, 2 = agak suka, 3 = suka, 4 = sangat suka

berlangsung pada zat-zat ini akan semakin menimbulkan warna coklat pada madu.

\section{b) Rasa}

Berdasarkan analisis sidik ragam pada Tabel 3 diketahui bahwa penggunaan madu sebagai pemanis memberikan pengaruh terhadap penerimaan panelis pada rasa velva yang dihasilkan. Rasa velva dengan pemanis madu $15 \%$ tidak berbeda nyata dengan rasa velva yang menggunakan pemanis madu $25 \%$, namun pada konsentrasi $35 \%$ terjadi perbedaan yang signifkan pada rasa velva tomat. Semakin tinggi konsentrasi madu yang ditambahkan, semakin tinggi tingkat kesukaan panelis terhadap rasa velva tomat. Hal ini dikarenakan kandungan salah satu gula utama yang terdapat pada madu yaitu fruktosa. Fruktosa memiliki rasa manis relatif yang lebih besar dibandingkan dengan sukrosa. Fruktosa memiliki rasa manis relatif sebesar 114, sedangkan sukrosa memiliki rasa manis relatif sebesar 100 (Buckle et al., 1987). Maka madu memiliki tingkat kemanisan yang lebih tinggi dibandingkan dengan sukrosa (gula). Suranto (2007) menyatakan bahwa rasa madu yang khas disebabkan oleh kandungan asam organik dan karbohidratnya, serta jenis nektarnya.

\section{c) Aroma}

Berdasarkan Tabel 3 diketahui bahwa konsentrasi pemanis madu pada velva tomat tidak memberikan pengaruh yang nyata terhadap tingkat kesukaan aroma pada konsentrasi $15 \%$, 25\%, dan 35\%. Namun velva tomat kontrol yang menggunakan pemanis sukrosa $25 \%$ memiliki beda nyata dengan velva tomat yang menggunakan pemanis madu 35\%. Penggunaan madu menurunkan tingkat kesukaan panelis terhadap aroma velva yang dihasilkan. Aroma velva tomat dengan penambahan madu sebagai pemanis didominasi oleh aroma madu.

\section{d) Tekstur}

Berdasarkan hasil analisa sidik ragam pada Tabel 3 diketahui bahwa penggunaan madu sebagai pemanis tidak mempengaruhi penerimaan panelis terhadap tekstur velva yang dihasilkan. Tekstur velva dengan pemanis madu $15 \%$ tidak berbeda nyata dengan tekstur velva dengan pemanis madu $25 \%$, namun pada konsentrasi $35 \%$ terjadi perbedaan yang signifikan pada tekstur velva tomat. Semakin tinggi konsentrasi madu yang ditambahkan, semakin tinggi tingkat kesukaan panelis terhadap tekstur velva tomat yang dihasilkan.

\section{e) Overall}

Berdasarkan hasil analisa sidik ragam pada Tabel 3 diketahui bahwa penggunaan madu sebagai pengganti sukrosa ternyata tidak memberikan pengaruh nyata terhadap tingkat kesukaan panelis pada parameter overall velva tomat. Namun velva tomat kontrol yang menggunakan pemanis sukrosa memberikan pengaruh beda nyata dengan velva tomat yang menggunakan pemanis madu. Nilai kesukaan terhadap parameter overall yang paling disukai adalah yang tertinggi yaitu velva tomat kontrol yang menggunakan sukrosa $25 \%$ sebagai pemanis. Hal ini menunjukkan bahwa velva tomat yang menggunakan pemanis sukrosa adalah velva tomat yang disukai panelis meliputi parameter warna, rasa, aroma, dan tekstur.

\section{Uji Intensitas Kemanisan}

Uji intensitas kemanisan merupakan uji untuk menilai perbedaan tingkat kemanisan produk. Uji ini dilakukan untuk 
Tabel 4. Hasil Uji Intensitas Kemanisan Velva Tomat dengan Variasi Konsentrasi Penambahan Madu.

\begin{tabular}{cc}
\hline Formula $^{*}$ & Tingkat Kemanisan $* *, * * *$ \\
\hline F1 & $6,20^{\mathrm{b}}$ \\
F2 & $1,93^{\mathrm{a}}$ \\
F3 & $2,50^{\mathrm{a}}$ \\
\hline
\end{tabular}

Keterangan : *) Kontrol = velva tomat pemanis gula 25\%, F1 = velva tomat dengan pemanis madu $15 \%, \mathrm{~F} 2=$ velva tomat dengan pemanis madu $25 \%, \mathrm{~F} 2$ = velva tomat dengan pemanis madu $35 \%$.

**) Angka yang diikuti huruf yang berbeda pada kolom yang sama menunjukan adanya beda nyata pada taraf $\operatorname{sig} \alpha=0,05$.

***) Keterangan skor :

$1=$ sedikit lebih manis dari kontrol

$2=$ cukup lebih manis dari kontrol

3 = banyak lebih manis dari kontrol

$4=$ sama manis dengan kontrol

$5=$ sedikit kurang manis dari kontrol

6 = cukup kurang manis dari kontrol

$7=$ banyak kurang manis dari kontrol

mengetahui intensitas rasa manis velva tomat yang ditambahkan madu sebagai pemanis dengan konsentrasi $15 \%$, 25\%, dan 35\%.

Pada Tabel 4 menunjukkan bahwa konsentrasi penggunaan madu memberikan pengaruh yang nyata terhadap tingkat kemanisan velva tomat. Penggantian pemanis sukrosa menggunakan madu pada velva tomat $25 \%$ dan $35 \%$ menghasilkan tingkat kemanisan yang lebih tinggi dibandingkan velva tomat dengan penggunaan pemanis sukrosa $25 \%$, sedangkan velva tomat dengan penggunaan pemanis madu menghasilkan tingkat kemanisan yang lebih rendah dibandingkan velva tomat kontrol dengan penggunaan pemanis sukrosa $25 \%$. Semakin tinggi konsentrasi penambahan madu, semakin tinggi tingkat kemanisan velva tomat. Rasa manis yang dihasilkan berasal dari kandungan fruktosa pada madu yang mempunyai tingkat kemanisan relatif lebih tinggi daripada sukrosa. Jika dibandingkan dengan uji kesukaan pada parameter mutu rasa, tingkat kesukaan panelis semakin meningkat dengan penggunaan konsentrasi madu. Hal ini berarti semakin tinggi konsentrasi penggunaan madu, semakin tinggi tingkat kesukaan panelis terhadap parameter mutu rasa velva tomat.

\section{KESIMPULAN}

1. Penambahan madu memberikan pengaruh pada karakteristik fisikokimia velva tomat berupa penurunan overrun dan kadar air (dengan kisaran overrun 22,12-15,76\% dan kadar air 87,70-71,98\% (wb)) terjadi pula peningkatan daya leleh, serat pangan, vitamin $\mathrm{C}$, total padatan terlarut, likopen, dan aktivitas antioksidan (dengan kisaran daya leleh 12 menit 47 detik-15 menit 10 detik, serat pangan $2,31-2,42 \%$, vitamin C 17,60-27,13 $\mathrm{mg} / 100 \mathrm{~g}$, total padatan terlarut $10,17-17,67^{\circ}$ Brix, likopen $10,96-$ $11,05 \mathrm{mg} / \mathrm{kg} \mathrm{bb}$, dan aktivitas antioksidan 62,90-67,60\%).

2. Penggunaan madu pada konsentrasi $15 \%$ $35 \%$ berpengaruh nyata terhadap skor penilaian uji hedonik (kesukaan) pada parameter warna, rasa, dan tekstur, namun tidak memberikan pengaruh yang nyata terhadap parameter aroma dan overall. Pada uji intensitas kemanisan (uji skoring) diketahui bahwa penambahan madu memberikan pengaruh yang nyata terhadap tingkat kemanisan velva. Velva tomat dengan konsentrasi penggunaan madu $15 \%$ memiliki tingkat kemanisan lebih rendah daripada sukrosa $25 \%$, sedangkan velva tomat dengan konsentrasi madu $25 \%$ dan $35 \%$ memiliki tingkat kemanisan yang lebih tinggi dibandingkan sukrosa $25 \%$.

\section{DAFTAR PUSTAKA}

Aji, Soleh Purwono. 2011. Kajian Penambahan Berbagai Jenis Madu sebagai Alternatif Pemanis Minuman Fungsional Sari Buah Naga Putih. 
Skripsi. Fakultas Pertanian. Universitas Negeri Sebelas Maret. Surakarta.

Arbukcle, W. S. dan R. T. Marshall. 1996. Ice Cream ( $5^{\text {th }}$ edition). Chapman and Hall, New York.

Ardiansyah. 2007. Antioksidan dan Peranannya bagi Kesehatan. www.chapterereislamic-

space.wordpress.com/2007/01/24/antioks idan-dan-peranannya-bagi-

kesehatan/32k. [Terhubung berkala]. Diakses pada hari Kamis 7 November 2013 pukul 14.30 WIB.

Badan Pusat Statistik Indonesia (BPS). 2013. Produksi Sayuran di Indonesia. http://www.bps.go.id/tab_sub/view.php? kat $=3 \&$ tabel $=1 \&$ daftar $=1 \&$ id_subyek $=5$ $5 \&$ notab $=27$. [Terhubung berkala]. Diakses pada hari Senin 4 Maret 2013 pukul 12.15 WIB.

Buckle, K.A., R.A. Edward., G. H. Fleet., and M. Wooton. 1987. Ilmu Pangan. Penerjemah : Hari Purnomo, Adiono. Cetakan pertama. Jakarta : UI-Press.

Chew, B. P. 1995. Antioxidant Vitamins Affect Food Animal Immunity and Health. J. Nutr. 125: 1804-1808.

Dewi, Rini Kartika. 2010. Stabilizer Concentration and Sucrose To The Velva Tomato Fruit Quality. Jurnal Teknik Kimia Vol.4, No.2, April 2010. Jurusan Teknik Kimia. Fakultas Teknologi Industri. Institut Teknologi Nasional Malang.

Ferreira, Isabel C.F.R., Edmur Aires, Joao C.M. Barreira, and Leticia M. Estevinho. 2009. Antioxidant activity of Portuguese honey samples: Different contributions of the entire honey and phenolic extract. CIMO/Escola Superior Agraria, Instituto Politecnico de Braganca, Campus de Santa Apolonia, Apartado 1172, 5301855 Braganca, Portugal.

Gheldof N, Wang Xiao-Hong, and Engeseth $\mathrm{N}$ J. 2002. Identification and Quantification of Antioxidant Components of Honeys from Various Floral Sources. Journal of Agricultural and Food Chemistry 50 : 5870-5877.
Gosyenland. 2010. Madu Versus Gula. http://www.gosyenland.com/front/index. php/artikel-madu/73-madu-vs-gula. [Terhubung berkala]. Diakses pada tanggal 24 Mei 2013 pukul 13.00.

Hammad . 2009. 99 Resep Sehat dengan Madu. Solo: Aqwamedika.

Kailaku, Sari Intan ., Kun Tanti Dewandari dan Sunarmani. 2007. Potensi Likopen dalam Tomat untuk Kesehatan. Balai Besar Penelitian dan Pengembangan Pascapanen Pertanian. Buletin Teknologi Pascapanen Pertanian Vol. 3 : 2007.

Muchtadi, D. 2000. Sayur-Sayuran Sumber Serat dan Antioksidan: Mencegah Penyakit Degeneratif. Jurusan Teknologi Pangan dan Gizi. Fakultas Teknologi Pertanian. Institut Pertanian Bogor. Bogor.

Muhsin B. 2008. Komposisi Madu dan Gula Pasir. http://www.mengkaji-sunnah.com. [Terhubung berkala]. Diakses pada tanggal 24 Mei 2013 pukul 13.45.

Parwata, I M. Oka Adi., K. Ratnayani, dan Ana Listya. 2010. Aktivitas Antiradikal Bebas serta Kadar Beta Karoten pada Madu Randu (Ceiba pentandra) dan Madu Kelengkeng (Nephelium longata L.). Jurnal Kimia 4 (1), Januari 2010 : 54-62.

Rizqa. 2013. Aneka Frozen Dessert. http://www.tekpangdessert.com.

[Terhubung berkala]. Diakses pada tanggal 27 Mei 2013 pukul 17.00.

Sakri, Faisal M. 2012. Madu dan Khasiatnya : Suplemen Sehat Tanpa Efek Samping. Jogjakarta : Diandra Pustaka Indonesia.

Setianawati, hijrah nora. 2002. Penggunaan kombinasi bahan penstabil pada pembuatan velva mangga kweni (Mangifera Odorata Griff.) dan Perubahan Mutu selama Penyimpanan. Skripsi. Jurusan Gizi Masyarakat dan Sumberdaya Keluarga. Fakultas Pertanian. Institut Pertanian Bogor.

Sihombing, D.T.H. 1997. Ilmu Ternak Lebah Madu. Gajah Mada University Press. Yogyakarta. 
Silalahi, J. dan Netty Hutagalung. 1994. Komponen-komponen Bioaktif dalam Makanan dan Pengaruhnya Terhadap Kesehatan.

http://www.tempo.co.id/medika/arsip/06 2002/pus-3.htm. [Terhubung berkala]. Diakses tanggal 17 Oktober 2013 Pukul 22.43 WIB.

Siregar, Mukhlidah H. 2012. Cara Sehat dengan Resep-resep Ajaib Herbal Islami. Jogjakarta : Buku Biru.

Standar Nasional Indonesia (SNI). Madu. SNI 01-3545-2004.

Suraningsih, Maya Safrina. 2000. Pengaruh Jenis dan Konsentrasi Bahan Penstabil terhadap Mutu Velva Sirsak. Skripsi. Fakultas Teknologi Pertanian. Institut Pertanian Bogor.

Suranto, A. 2007. Terapi Madu. Jakarta : Penebar Plus.

Thompson, K. A., M. R. Marshall, C. A. Sims, S. A. Sargent, dan J. W. Scott. 2000. Cultivar, Maturity, and Heat Treatment on Lycopene Content in Tomatoes. Journal of Food Sci. Vol. 65. No. 5:791-795.

Winarno, F. G. 2004. Kimia Pangan dan Gizi. Jakarta : PT. Gramedia Pustaka Utama. 